УДК 792.028

DOI: 10.31866/2616-759x.2.2018.153244

Юдов Микола Олександрович, заслужений праиівник культури Украӥни,

дочент,

Київський національний університет

культури і мистецтв,

Киї, Україна

m.o.yudov@gmail.com.

ORCID: https://orcid.org/0000-0002-9887-0834

Юдова-Романова Катерина Володимирівна, кандидат мистецтвознавства, доцент, докторант, Київький національний університет культури і мистеитв, Київ, Україна iudovakateryna@gmail.com ORCID: https://orcid.org/0000-0003-2665-390X

Полюк Назар Тарасович, мaгicmp,

Музичний телеканал «MusicBoxUA» світової мережі Music Box Group,

Київ, Украӥна

poliukjob@gmail.com

ORCID: https://orcid.org/0000-0002-7307-7338

\title{
ЗНАЧЕННЯ ЕМОЦЙНОГО СЛУХУ Й ЕМПАТІЇ В МИСТЕЦТВІ АКТОРА
}

Мета дослідження - проаналізувати роль емоційного слуху й емпатії як складників роботи актора над сценічним образом у контексті вдосконалення сучасної театральної педагогіки. Методологія дослідження базується на таких основних принципах: принципі об'єктивності, завдяки якому роль емоційного слуху й емпатії в мистецтві актора розглядається в історико-мистецтвознавчо-педагогічному розрізі в усій їхній складності, багатовимірності та суперечливості, 3 урахуванням сукупності позитивних і негативних сторін їхнього змісту; принципі науковості, з використанням якого з'ясовуються причиннонаслідкові зв'язки між науково перевіреними знаннями, що відповідають сучасному рівню розвитку науки про мовний, емоційний слухи й емпатію актора i їхнє значення у виконавському мистецтві; принципи розвитку та взаємодії, відносності, цілісності, практичності дають змогу розглядати названі феномени комплексно та простежувати тенденційні процеси. Зазначена методологія сприяє розкриттю значущості окресленої проблематики 3 точки зору практичного мистецтвознавства крізь призму педагогічних аспектів. Наукова новизна. Дослідження вчених-психологів, практиків театрального мистецтва та педагогів свідчать про вагомість емоційного слуху й емпатії в людському i, зокрема, сценічному спілкуванні. У процесі дослідження виявлено безпосередній зв'язок між рівнем емоційного слуху й емпатії актора та його художньою потенцією до створення високохудожніх сценічних образів. Висновки. Стверджується, що важливе значення у сприйнятті людини має слух - мовний та емоційний. У мистецтві актора обидва його види 
виконують провідну роль - і в роботі акторської уяви в процесі створення художнього образу, і в діалогічному спілкуванні з партнерами на сцені та 3 глядачем. Для сучасного актора важливо розвивати в собі не лише мовний та емоційний слухи, а й емпатію здатність до переживання і активного, і пасивного. Зазначено, що природа імпровізаційної творчості в мистецтві актора безпосередньо пов'язана 3 такими характеристиками, як емоційний слух та емпатія.

Ключові слова: емоційний слух; емпірія; мовний слух; мистецтво актора; акторська уява; сценічне мовлення.

Постановка проблеми. Віртуальна реальність, штучний простір, створений завдяки комп'ютерам та Інтернету, призвичаїли людство до спілкування у віртуальному світі, де сьогодні відбувається значна частина контактів між людьми. Але віртуальне спілкування людей не може замінити реальне, адже в реальних відносинах домінують емоції, а не просто обмін інформацією. Тенденція до зниження практики живого спілкування призводить до втрати навичок сприймати оточуючих на емоційному рівні.

Професія актора природою самої творчості артиста цілком залежна від таланту живого спілкування: 3 партнером, з публікою. Умови сучасного життя сприяють тенденціям, де процес діалогічного мовлення актора на сцені замінюється поверховим обміном інформацією. Спілкування позначається, а не проживається повною мірою. Звичка до формального обміну репліками 3 донесенням певної інформації не дає акторові змоги вловлювати чуттєві, енергетичні імпульси партнера. Часто актори на сцені не «чують» так, як повинен «чути» драматичний актор.

Аналіз останніх досліджень та публікацій. Дослідження проблем емоційного слуху та емпатії вчених Л.П. Журавльової, В.П. Морозова, В.М. Вундта, М.М. Шпак, Л.В. Щерби та ін. зосереджені на процесах людського спілкування загалом. У працях К.С. Станіславського, М.О. Чехова, а також у роботах інших видатних майстрів театру - М.Й. Кнебель, Є. Гротовського, Г.О. Товстоногова, Б.С. Захави - глибоко й системно досліджуються особливості та етапи роботи актора. При цьому митці звертаються до проблем емоційного слуху й емпатії переважно побіжно та опосередковано, крізь призму роботи актора над створенням сценічного образу. П.В.Сімонов у своїх дослідженнях зосереджує увагу на широкому спектрі проблем фізіології емоцій у контексті оволодіння методом К.С. Станіславського. Л.Г. Беркова-Житомирська предметно розглядає педагогічні аспекти розвитку емоційного слуху, зокрема в процесі вокальної підготовки акторів драми. Більш конкретно, інколи 3 акцентом на методиці розвитку емоційного слуху й емпатії як складників сценічного мовлення актора вивчають означену проблему фахівці-педагоги: Б.Д. Антоненко-Давидович, А.О. Гладишева, Н.В. Грицан, Ю.В. Раденко, О.Ф. Сарічева, І.І. Сорока та ін. Натомість дослідження i вчених-психологів, і практиків театрального мистецтва та педагогів носять різновекторний характер і лише фрагментарно розкривають значення емоційного слуху й емпатії у мистецтві актора.

Мета дослідження - проаналізувати роль емоційного слуху й емпатії як складників роботи актора над сценічним образом у контексті вдосконалення сучасної театральної педагогіки. 
Виклад основного матеріалу. Емоції - суб’єктивні реакції людини на дію внутрішніх і зовнішніх подразників, що виявляються у вигляді задоволення або незадоволення, радості, страху й ін. Емоції відображаються у формі безпосереднього переживання явищ та ситуацій і слугують одним 3 основних механізмів внутрішньої регуляції психічної діяльності та поведінки, спрямованих на задоволення актуальних потреб (мотивації).

Численні наукові дослідження показали статистично надійну кореляцію емоційного слуху з такою психологічною характеристикою, як емпатія, тобто здатністю до співпереживання та емоційної чуйності. Дослідження емпатії підтвердили, що групи осіб з високим рівнем емоційного слуху мають доволі виражену емпатію - близько 47-50 балів, а групи 3 низьким емоційним слухом 20-30 балів. Статистичні дослідження виявили наявність позитивних кореляцій між показниками емоційного слуху й емпатією. Отже, можна стверджувати, що емоційний слух $є$ важливим складником емпатії (Морозов, 1991).

Варто наголосити, що емоційний зміст промови незалежний від текстового. Значення слова саме по собі позаемоційне: емоція, оцінка, експресія народжуються в процесі його безпосереднього вживання в конкретному висловлюванні. Навіть слова, які спеціально позначають емоції, іiї оцінки (радість, скорботу, веселощі, сум тощо), також нейтральні, як і всі інші. Скажімо, фраза «Яка радість!» у лексичному змісті містить експресію, але емоційного забарвлення вона набуває лише у висловлюванні в процесі спілкування. У звуково-інтонаційному втіленні емоційний зміст може бути прямо протилежний словесному значенню, а саме висловлювання може набути іронічного або гірко-саркастичного тону. Отже, емоційний зміст $є$ оболонкою, що має місце у мовному спілкуванні під час безпосереднього переживання співрозмовниками (Кэррол, 2008).

У діалогічному мовленні завжди наявний емоційний контекст, який визначається ставленням мовця чи до особистості співрозмовника, чи до предмета розмови. Саме емоція визначає наше сприйняття і ставлення до навколишнього світу. Тому ті самі предмети, люди, явища та події в різних емоційних станах сприймаються по-різному.

За визначенням відомого американського психолога Ізарда Керрола, емоція - це щось, що переживається як почуття (feeling), яке мотивує, організовує і спрямовує сприйняття, мислення й дії. Іншими словами, мотивація певного вчинку мобілізуе енергію людини й спонукає іiі до дії. Наша фізична й розумова активність виплескується емоцією. Так, людина, охоплена гнівом, поводиться інакше, ніж коли відчуває страх або горе. Емоції різноманітні; вони, пронизуючи все життя людини, можуть бути короткочасними, а можуть тривати годинами. Але хоч якою б інтенсивною була емоція - вона завжди викликає фізіологічні зміни в організмі, спонукає до відповідної поведінки. Якщо бути уважним, то лише за однією позою, за кількома характерними рухами людини можна визначити, яку емоцію вона переживає в цю мить (Кэррол, 2008). Відомим дослідником цього напряму вивчення людської поведінки став А. Піз (2015). Емоція, безперечно, проявляється і в мові людини, наповнюючи їі змістом та емоційними барвами.

Різні вегетативні й фізіологічні реакції, що виникають на тлі емоційних впливів, характеризується так: зміни в ритмі дихання, особливо скорочення 
фази видиху, фонації, що $є$ мимовільним переходом до невластивих тонів і тембру голосу, артикуляції, а саме: заковтування слів, заїкання, розтягування пауз між словами або складами, що простежуються в їхніх граматичній побудові, логічності. Темп мовлення також може свідчити про емоційний стан людини. Як правило, швидкість мови зростає, коли вона схвильована, збуджена чи стурбована. Швидко говорить і той, хто намагається переконати свого співрозмовника. Повільна ж мова часто свідчить про пригнічений стан або втому. Індикатором сили почуттів може слугувати й сила звуку.

Розуміння терміна мовного слуху містить здатність до розрізнення і сприйняття перелічених характеристик, однак мовного слуху недостатньо для сприйняття емоційності мови. Сприйняття емоційного змісту висловлювання здійснюється через акустичні засоби вираження (темброві, інтонаційні), що простежується на прикладах акторського декламування та під час виконання вокально-музичних уривків. Ця особливого роду інформація (а саме: інформація про емоційний зміст висловлювання) сприймається іншим, відмінним від мовного, слухом - емоційним.

Поняття емоційного слуху було введено в науку про слух у 1985 p. професором, доктором біологічних наук, автором наукових праць 3 вивчення голосу, мови й слуху В. Морозовим для виявлення емоційної сприйнятливості та емоційної чуйності. Емоційний слух, на думку В. Морозова, - це здатність розпізнавати емоційний стан мовця за звуком його голосу на основі інтонації, тембру. Терміном «емоційний слух» у загальній формі запропоновано позначати здатність людини до вираження і сприйняття емоційного забарвлення (інтонація, виразність) голосу в мові та співі, а також інструментальної музики.

Педагог Запорізького національного університету Л.Г. Беркова-Житомирська, досліджуючи проблеми розвитку емоційного слуху в процесі вокальної підготовки акторів драматичного театру, стверджує, що «емоційність має дві форми прояву: активну (емоційна виразність власного голосу) і пасивну (емоційна сприйнятливість як здатність сприймати емоційний контекст чужого голосу). Пасивна форма є первинною, тобто визначає другу, активну форму, згідно з давно доведеним на практиці педагогічним законом: нічого не може бути в діях людини, чого раніше не було в іiі сприйняттях». Далі автор приходить до висновку: «позбавлений емоційного сприйняття той, хто не вразливий до емоційного змісту чужого голосу» (2010, с.57).

Емоційний слух має такі різновиди:

- тембровий емоційний слух уловлює зміну тембрового складу голосу в різних емоційних станах;

- інтонаційно-мелодійний емоційний слух дає змогу почути емоційний стан у зміні тону, мелодійного малюнка фрази, визначається здатністю почути емоційний стан у звучанні скрипки, у свисті, в мовній фразі, позбавленій змісту;

- темпоритмічний емоційний слух сприймає зміну темпу мови і співвідношення між часом інтонування й паузами в тексті, проявляється здатністю розпізнати емоційний стан у ритмічному перестуку;

- динамічний емоційний слух вловлює зміни емоційного стану через зміну потужності мовного сигналу. Наприклад, активно пережиті емоції: радість, захоплення та ін., супроводжуються, як правило, збільшенням потужності мовного сигналу (Морозов, 1994, с.90-91). 
Емоційний слух поділяється на активний і пасивний: здатність правильно розпізнати емоцію - це пасивна форма емоційного слуху; здатність виражати почуття голосом або за допомогою музичного інструменту визначається активним емоційним слухом. Саме ця якість має бути притаманною виконавцям - чи то акторам, чи вокалістам, чи музикантам.

У психологічному словнику термін «емпатія» тлумачиться як притаманна особистості здатність емоційно озиватися на переживання, почуття і психічні стани інших людей. Емпатія виражається у суб`єктивному сприйнятті емоцій іншої людини, в умінні ототожнитися 3 нею, проникати в іiї внутрішній світ, перейматися переживаннями, думками та почуттями інших. Зрештою, емпатія сприяє людському взаєморозумінню, щирому та довірчому спілкуванню (Психологічний словник).

Вирізняються такі основні форми емпатії:

- співпереживання - переживання суб'єктом тих самих емоційних станів, які відчуває інша людина через ототожнення з нею;

- співчуття - набуття власних емоційних станів під впливом почуттів іншої людини.

Психологи виділяють три рівні емпатії:

1-й рівень - найнижчий, це сліпота до почуттів і думок інших. Такі люди зайняті винятково собою; їм може здаватися, що вони знають і розуміють інших людей, але вони помиляються. Низький рівень емпатії спрямовує людей до стану соціального аутизму, про який психологи ведуть мову як про «хворобу XXI століття», що дедалі більше переслідує сучасне суспільство.

2-й рівень - епізодична сліпота до почуттів та думок інших. Він властивий більшості людей, незалежно від типу їхньої особистості.

3-й рівень - найвищий. Це здатність до сприйняття внутрішнього світу людини, уявне відтворення її переживань, відчуття їх як власних. Такі люди, як правило, належать до мистецького типу особистості та мають високий рівень емоційного слуху (Беркова-Житомирська, с.58).

За твердженням американського психолога К. Роджерса, емпатія вимагає глибокої напруженої роботи духу. Поринути у світ іншої людини, з усіма його радощами й тривогами, сприйняти, як вона сприймає, зрозуміти причини емоцій, як вона їх розуміє, бути чутливим до мінливих переживань іншого, вловлювати емоційні і смислові відтінки його висловлювань, тобто «увійти в особистий світ іншого й перебувати в ньому «як удома»» - ось що таке емпатійне спілкування за К. Ролджерсом. Але, застерігає К. Роджерс, перебувати делікатно, без оцінювання й засудження (1984). Як тут не провести паралель із уведеним К.С. Станіславським до театральної педагогіки, режисури та мистецтва актора спеціального терміна «якби», «магічного, творчого якби». «Якби», «Магічне якби», «Творче якби» - запропонований у системі К.С. Станіславського прийом творчого перевтілення в сценічний образ, який полягає в тому, що актор створює в своїй уяві певні обставини зовнішнього середовища і ставить перед собою питання: «Що б я став робити, якби ці обставини були б не вигадкою уяви, а справжньою реальністю?» Прийом «Якби» К.С. Станіславського запобігає появі на сцені штампів та спонукає до самостійного творчого мислення на основі п’єси і іiї режисерського тлумачення. 
Досліджуючи емпатію, відомий західний психолог і соціолог Е. Фромм у своїй праці «Душа людини» наводить яскравий приклад емпатійного прояву (1992). Вчений описує стосунки матері й дитини: будь-які зміни в тілі дитини, iii потреби або занепокоєння мати відчуває перш, ніж вони проявляться; вона прокидається від плачу своєї дитини, тоді як інші гучніші звуки її не будять.

Приклади емпатійного спілкування пропонує психолог В. Леві в монографії «Мистецтво бути іншим» - як з півслова, 3 пів погляду розуміють одне одного закохані. Неперевершені емпатії, вважає дослідник, мають собаки, тож він бачить глибокий сенс у тому, що собаки й господарі часто схожі (2013).

Істинно глибинне спілкування відбувається лише через відчуття себе іншим. Певно, що справжнє розуміння іншої людини неможливе без розвиненої уяви. Щоб співпереживати прикрощам i радощам іншої людини, потрібно за допомогою уяви стати на їі місце. У взаємодії з іншим і корінь розуміння природи художньої творчості. Розвинена творча уява - одна із провідних рис, притаманних талановитим митцям, зокрема i артистам. Широко відомим $\epsilon$ висловлювання Г. Флобера про те, що в моменти опису смерті Емми Боварі він відчував смак отрути на своїх губах. Однак чи не існує тісний зв’язок між автором, або ж творцем художнього образу на сцені, проявом вищого ступеня емпатії, чи не є емоційна реактивність свідченням високого рівня емоційного слуху?

Емпатія відкриває шлях до розуміння іншої людини. Починається із зацікавленого стану, закінчується зацікавленням долею. Такі ж «гарячі» (за визначенням Г. 3. Леві) взаємини виникають в актора з образом.

Про співчуття до образу говорив М. Чехов: «... художній образ, який поставав перед моїм внутрішнім поглядом, був відкритий для мене до кінця 3 усіма його емоціями, почуттями і пристрастями, з усіма задумами, цілями і найпотаємнішими бажаннями» (1986, с.182). Завдяки акторській уяві і творчій інтуїції можливе таке поступове проникнення у внутрішнє життя образу. Крок за кроком, вирішуючи завдання про найдрібніші нюанси поведінки, ставлення до інших персонажів, про характерні риси свого героя, пильно спостерігаючи за внутрішнім життям образу із його зовнішніми проявами, актор «через зовнішню оболонку» занурюється в світ його душі.

Слід наголосити, що емпатія ніколи не переходить у повну ідентифікацію. У К. Роджерса обов'язкова присутність відтінку «начебто»: як ніби це я радію або засмучуюсь. При цьому психолог зауважує: «Бути в стані емпатії означає сприймати внутрішній світ іншого точно, зі збереженням емоційних і смислових відтінків. Неначе стаєш цим іншим, але без втрати відчуття «начебто». Так, відчуваєш радість або біль іншого, як він ї відчуває, i сприймаєш їх причини, як він їх сприймає. Але обов’язково повинен залишатися відтінок «начебто»: начебто це я радію або засмучуюсь. Якщо цей відтінок зникає, то виникає стан ідентифікації» (1975, р.23). Про це ж розмірковує і М. Чехов. Художній образ існує самостійно, актор лише вслід за ним, творячи, пізнає і вчиться панувати над ним. Припасовуючи образ до себе, до своїх особистих почуттів, актори забувають, що їхні особисті почуття говорять їм лише про них самих і нічого не можуть сказати про роль. Тільки співчуття здатне проникнути в чужу душу і будувати «душу» сценічного образу. 
«Співчуття, співрадість, співкохання» - так М. Чехов характеризує ставлення актора до свого образу (http://drugie-berega.my1.ru/publ/theatre/27-1-0-15).

Найвищу ступінь емпатії характеризує і висловлювання М. Щепкіна про те, що актор повинен не копіювати життя, а вникати «в душу ролі», влізати «в шкуру дійової особи ...» (1952, с.243-245, 251, 256,). Таке емпатійне спілкування актора зі створюваним в його уяві образом, який сприймається актором як жива людина, відрізняє великих артистів, справжніх майстрів сцени, незалежно від того, де вони служать - у музично-драматичному театрі чи на естраді. Спогади К. Шульженко ілюструють це твердження. Співачка розповідає про свою роботу над піснею «Три вальси», яка тривала понад два роки. Весь цей час Шульженко пильно спостерігала за людьми, відбирала найдрібніші деталі їхньої поведінки, які, як їй здавалося, були характерні для героїв пісні. Вона намагалася відшукати їхні прототипи в студентському середовищі, де не раз виступала, на зустрічах із творчою інтелігенцією або просто в гостях чи вдома. Співачка згадує, що шукала своїх героїв усюди: «в романах, на сцені, на екрані» (1985, с.21). Лише після того, як артистка відчула, що добре знає своїх героїв, може розповісти їх біографії, знає, як вони поводяться в тих чи інших життєвих ситуаціях, вона взялася за репетиції пісні. На глибоке переконання К. Шульженко, в кожній пісні виконавець розповідає про інших, як про себе. «І глядач вірить: все, що відбувається 3 героєм, відбулося з самим співаком, пережито ним, відчуте» (1985, с.39).

Емпатійний актор і стосовно партнерів. Він повинен бути відкритий і сприйнятливий навіть до ледве помітного імпульсу, що виходить від партнера. Емпатійне спілкування мимоволі виникає в умовах будь-якої гри: хлопчики у дворі, боксери на рингу, тенісисти на корті. Грі притаманні ризик i змагальність; вона вимагає пильної уваги до партнера. Якщо в дитячій або спортивній грі увага «вмикається» сама, то для актора це вольовий акт. Сценічне спілкування вимагає уваги до партнера, «зараження» об’єктом. Саме це слово вживає старий актор Шустов у книжці К. Станіславського «Робота актора над собою», пояснюючи акторам-учням, що таке спілкування: «Заражай, заражай об’єкт! «Влазь у його душу» і сам сильніше заразишся! А сам заразишся і інших сильніше заражатимеш. Тоді і мовлення твоє стане більш запальним» (http://az.lib.ru/s/stanislawskij_k_s/text). Діалог для Шуства це емоціне зарядження («зараження») його учасників.

Варто особливо відзначити, що емпатія немислима без тонко розвиненого емоційного слуху. Це твердження неодноразово доведено науковими експериментами. Водночас високий показник емоційного слуху може не означати високого рівня емпатії. Якщо емоційний слух властивий людині від природи, то емпатійність пов’язана з особистісними цінностями людини та контекстом ії життєвих обставин.

Розвивати в акторів щирість, безпосередність, «дитяче» сприйняття, здатність до співчуття - про це мають дбати і професійні актори, і студенти акторських спеціальностей під керівництвом педагогів. Професійні актори i студенти мають розвивати в собі емпатійні здібності. Встановлено, що розвиткові емпатії сприяє розвиток емоційного слуху. Слід особливо наголосити, що високий рівень емпатії неможливий у людини 3 низьким 
показником емоційного слуху. Лише актора, здатного до емпатійного спілкування, можна навчити присутності в діалозі, цілком і повністю бути «тут» і «зараз», не чекати своєї репліки, для якої вже заготовлені виразні інтонації, а вести 3 партнером азартну гру, в якій акторська природа розкривається в усій розмаїтості й непередбачуваності. Розвиток цих якостей пов’язаний iз розвитком емоційного слуху й емпатії, - зазначає М. М. Бахтін (1986, с.80).

Методика викладання студентам акторських спеціальностей дисципліни «Сценічне мовлення» підпорядкована головній меті навчання - оволодінню навичками діалогічного мовлення, необхідною умовою якого $є$ розвинений емоційний слух та емпатія. Практичний досвід педагогів дає підставу для твердження, що емоційний слух та емпатія мають на заняттях із сценічного мовлення активно розвивається, а розвиток емоційного слуху й емпатії стає невід’ємною частиною виховання слухової сприйнятливості та інтонаційної виразності мовлення актора.

Наукова новизна. Отже, дослідження вчених-психологів, практиків театрального мистецтва та педагогів свідчать про вагомість емоційного слуху й емпатії в людському i, зокрема, сценічному спілкуванні. У процесі дослідження виявлено безпосередній зв’язок між рівнем емоційного слуху й емпатії актора та його художньою потенцією до створення високохудожніх сценічних образів.

Висновки. Важливе значення у сприйнятті людини має слух - мовний та емоційний. У мистецтві актора обидва види виконують провідну роль i в роботі акторської уяви в процесі створення художнього образу, і в діалогічному спілкуванні з партнерами на сцені та з глядачем. Для сучасного актора важливо розвивати в собі не лише мовний та емоційний слухи, а й емпатію - здатність до переживання і активного, і пасивного. Зазначено, що природа імпровізаційної творчості в мистецтві актора безпосередньо пов’язана $з$ такими характеристиками, як емоційний слух та емпатія.

У запропонованому дослідженні емоційного слуху та емпатії у мистецтві актора залишилися поза увагою проблеми методики їх вдосконалення, що в майбутньому може стати предметом осмислення результатів окремого педагогічного науково-дослідного експерименту із залученням і викладачів та студентів акторських спеціальностей, і професійних акторів.

\section{Список посилань}

Бахтин, М.М., 1986. Эстетика словесного творчества. Москва: Искусство.

Беркова-Житомирська, Л.Г., 2010. Емоційний слух та його значення для майбутнього актора. Вісник Запорізького національного університету, [online] 1, с.57-61. Доступно: $<$ http://web.znu.edu.ua/herald/issues/2010/Ped-1-2010/057-61.pdf> [Дата звернення 1 листопада 2018].

Кэррол, И.Э., 2008. Эмоции человека. Москва: Директ-Медиа.

Леви, В.Л., 2013. Искусство быть другим. Москва: Озон.

Морозов, В.П., 1991. Эмоциональный слух и методы его исследования. В: И.А. Даниленко и В.Н. Носуленко, ред. Проблемы экологической психоакустики. Москва: ИП РАН. с.240-246. 
Морозов, В.П., 1994. Художественный тип личности: новые критерии в системе комплексного подхода к разработке проблемы на модели музыкального искусства. В: В.П. Морозов и А.С. Соколов,ред. Художественный тип человека. Комплексные исследования. Москва. с.86-102.

Пиз, А. и Пиз, Б., 2015. Язык телодвижений. Москва: Эксмо.

Побірченко, Н.А. ред., 2007. Психологічний словник. Київ: Науковий світ. [online] Доступно: <http://elibrary.kubg.edu.ua/id/eprint/5980/3/o_serhieienkova_il.pdf> [Дата звернення 01 листопада 2018].

Роджерс, К., 1984. Эмпатия. В: В.К. Вилюнас и Ю.Б. Гиппенрейтер, ред. Психология эмоций. Москва: Наука.

Станиславский, К.С., 2012. Работа над собой в творческом проиессе воплощения. Дневник ученика. Азбука. [online] Доступно: <http://az.lib.ru/s/stanislawskij_k_s/text_ 0050.shtml.> [Дата обращения 01 ноября 2018].

Фромм, Э., 1992. Душа человека. Москва: Республика.

Чехов, М.А., 1986. Литературное наследие. В: Об искусстве актёра. Москва. Т.2.

Чехов, М.А., 2012. Творческая индивидуальность. [online] Доступно: <http://drugieberega my1 ru/publ/theatre/27-1-0-15> [Дата обращения 01 ноября 2018].

Шульженко, К., 1985. «Когда вы спросите меня...». Москва: Молодая гвардия.

Щепкин, М.С., 1952. Записки: Письма. Современники о М.С. Щепкине. Москва: Искусство.

Rogers, C.R., 1975. Empathic: An unappreciated way of being. The Counseling Psychologist, 5, pp.2-10. DOI: $10.1177 / 001100007500500202$

\section{References}

Bahtin, M.M., 1986. Estetika slovesnogo tvorchestva[Aesthetics of verbal creativity]. Moscow: Iskusstvo

Berkova-Zhytomyrska, L.H., 2010. Emotsiinyi slukh ta yoho znachennia dlia maibutnoho aktora [Emotional rumor and its significance for the future actor]. Visnyk Zaporizkoho natsionalnoho universytetu, [online] 1, p.57-61. Avialable at: <http://web.znu.edu.ua/herald/issues/2010/Ped-1-2010/057-61.pdf> [Accessed 1 November 2018].

Kerrol, I.E., 2008. Emotsii cheloveka [Emotions of a person]. Moscow: Direkt-Media. Levi, V.L., 2013. Iskusstvo byit drugim [The art of being different]. Moscow: Ozon.

Morozov, V.P., 1991. Emotsionalnyiy sluh i metodyi ego issledovaniya. [Emotional hearing and methods of his research]. In: I.A. Danilenko and V.N. Nosulenko, eds. Problemyi ekologicheskoy psihoakustiki. Moscow: IPRAN. p.240-246.

Morozov, V.P., 1994. Hudozhestvennyiy tip lichnosti: novyie kriterii v sisteme kompleksnogo podhoda k razrabotke problemyi na modeli muzyikalnogo iskusstva [Artistic personality type: new criteria in the system of an integrated approach to developing a problem on the musical art model] In: V.P. Morozov and A.S. Sokolov, eds. Hudozhestvennyiy tip cheloveka. Kompleksnyie issledovaniya. Moscow. p.86-102.

Piz, A. and Piz, B., 2015. Yazyik telodvizheniy [Language of body movements]. Moscow: Eksmo.

Pobirchenko, N.A. ed., 2007. Psykholohichnyi slovnyk [Psychologicaldictionary]. Kyiv: Naukovyi svit. [online] Available at: <http://elibrary kubg.edu.ua/id/eprint/5980/3/o_ serhieienkova_il.pdf> [Accessed 01 November 2018].

Rodzhers, K., 1984. Empatiya [Empathy]. In: V.K. Vilyunas and Yu.B. Gippenreyter, eds., Psihologiya emotsiy. Moscow:Nauka. 
Stanislavskiy, K.S., 2012. Rabota nad soboy v tvorcheskom protsesse voploscheniya. Dnevnik uchenika. Azbuka [Work on yourself in the creative process of realization. Student's diary. ABC]. [online] Available at: <http://az.lib ru/s/stanislawskij_k_s/text_0050.shtml> [Accessed 01 November 2018].

Fromm, E., 1992. Dusha cheloveka [Soul of man]. Moscow:Respublika.

Chehov, M.A., 1986. Literaturnoe nasledie [Literary heritage]. In: Ob iskusstve aktYora. Moscow. Vol.2.

Chehov, M.A., 2012. Tvorcheskaya individualnost [Creative individuality]. [online] Available at: <http://drugie-berega my1 ru/publ/theatre/27-1-0-15> [Accessed 01 November 2018].

Shulzhenko, K., 1985. «Kogda vyi sprosite menya...» [When you ask me]. Moscow: Molodaya gvardiya.

Schepkin, M.S., 1952. Zapiski: Pisma. Sovremenniki o M.S. Schepkine [Notes: Letters. Contemporaries about MS Shchepkine]. Moscow: Iskusstvo.

Rogers, C.R., 1975. Empathic: An unappreciated way of being. The Counseling Psychologist, 5, p.2-10. DOI: $10.1177 / 001100007500500202$.
(C) Юдов М.O., 2018
(C) Юдова-Романова К.В., 2018
(C) Полюк H.T., 2018 


\section{Yudov Mykola, Honored Worker of Culture of Ukraine, Associate Professor, Kyiv National University of Culture and Arts, Kyiv, Ukraine \\ Iudova-Romanova Kateryna, $\mathrm{PhD}$ in Art Studies, Associate Professor, Doctoral Student, Kyiv National University of Culture and Arts, Kyiv, Ukraine \\ Poliuk Nazar, Master, Musical Channel «Music Box UA» of World Network Music Box Group, Kyiv, Ukraine}

\section{THE VALUE OF EMOTIONAL HEARING AND EMPATHY IN THE ACTOR'S ART}

The purpose of the article is to analyse the emotional hearing role and empathy as components of the actor's work on a stage image in the improving modern theatrical pedagogical context. Methodology of the research is based on the main methodological principles: the objectivity principle, which allows the author to consider the emotional hearing role and empathy in the historical-art-pedagogical section in all their complexity, multidimensionality and contradiction, taking into account the totality of positive and negative aspects of their content; the scientific principle clarifies the causal relationships between scientifically verified knowledge that correspond to the current development level of the language science, emotional rumors and actor's empathy and their significance in performing arts; the development principles and interaction, relativity, integrity, practicality provide an opportunity for authors to consider these phenomena complex and trace trends. Taken together, this methodology provides an opportunity to reveal the outlined problem significance in terms of practical art studies through the prism of pedagogical aspects. The scientific novelty. Researches by both psychologists and practitioners of theatrical art and teachers show the importance of emotional hearing and empathy in the human process and, in particular, stage communication. In the research course, a direct relationship was found between the emotional hearing level and the empathy of the actor and his artistic potency to create highly artistic stage images. Conclusions. It would be legitimate to say that speech and emotional hearing play an important role in the human perception process. In the actor art, they play a leading role, both in the acting imagination work in the creating an artistic image process, and in dialogical communication with partners on the stage and with the audience. For a modern actor, it is important to develop not only speech and emotional rumors, but also empathy there is the ability to experience both active and passive. It is also worth noting that the nature of improvisational creativity in the actor art is directly related to such characteristics as emotional hearing and empathy.

Key words: emotional hearing; empathy; speech hearing; the actor art; acting imagination; stage speech. 
Юдов Николай Александрович, заслуженный работник культуры Украины, дочент, Киевский национальный университет культуры и искусств, Киев, Украина

Юдова-Романова Екатерина Владимировна, кандидат искусствоведения, доцент, докторант, Киевский национальный университет культуры и искусств, Киев, Украина

Полюк Назар Тарасович, магистр, Музыкальный телеканал «МиsicBoхUA» Всемирной сети Music Box Group, Киев, Украина

\section{ЗНАЧЕНИЕ ЭМОЦИОНАЛЬНОГО СЛУХА И ЭМПАТИИ В ИСКУССТВЕ АКТЁРА}

Цель исследования - проанализировать роль эмоционального слуха и эмпатии как составляющих работы актера над сценическим образом в контексте совершенствования современной театральной педагогики.

Методология исследования базируется на таких основных принципах: принципе объективности, благодаря которому авторам роль эмоционального слуха и эмпатии в искусстве актера рассматривается в историко-искусствоведческо-педагогическом разрезе во всей их сложности, многомерности и противоречивости, с учетом совокупности положительных и отрицательных сторон их содержания; принципе научности, с использованием которого выясняются причинно-следственные связи между научно проверенными знаниями, соответствующими современному уровню развития науки о речевом, эмоциональном слухах и эмпатии актера и их значении в исполнительском искусстве; принципы развития и взаимодействия, относительности, целостности, практичности предоставляют возможность авторам рассматривать данные феномены комплексно и прослеживать тенденциозные процессы. Указанная методология позволяет раскрыть значимость данной проблематики с точки зрения практического искусствоведения сквозь призму педагогических аспектов. Научная новизна. Исследования ученыхпсихологов, практиков театрального искусства и педагогов свидетельствуют о весомости эмоционального слуха и эмпатии в человеческом и, в частности, сценическом общении. В процессе исследования выявлена непосредственная связь между уровнем эмоционального слуха и эмпатии актера и его художественной потенцией к созданию высокохудожественных сценических образов. Выводы. Утверждается, что важное значение в восприятия человека имеет слух - речевой и эмоциональный. В искусстве актера оба его виды выполняют ведущую роль - как в работе актерского воображения в процессе создания художественного образа, так и в диалогическом общении с партнерами на сцене и со зрителем. Для современного актера важно развивать в себе не только речевой и эмоциональный слухи, но и эмпатию - способность к переживанию как активному, так и пассивному. Отмечено, что природа импровизационного творчества в искусстве актера непосредственно связана с такими характеристиками, как эмоциональный слух и эмпатия.

Ключевые слова: эмоциональный слух; эмпатия; речевой слух; искусство актера; актерское воображение; сценическая речь. 